\title{
Chromosomal Mapping of Murine c-fes and c-src Genes
}

\author{
CILA BLATT, ${ }^{1 *}$ MARY E. HARPER,,${ }^{1}$ GENOVEFFA FRANCHINI, ${ }^{2}$ MURIEL N. NESBITT, ${ }^{3}$ AND MELVIN I. \\ SIMON $^{1}$ \\ The Agouron Institute, La Jolla, California $92037^{1}$; Laboratory of Tumor Cell Biology, National Cancer Institute, \\ Bethesda, Maryland 20205²; and Department of Biology, University of California, San Diego, La Jolla, California $92093^{3}$
}

Received 27 October 1983/Accepted 2 January 1984

\begin{abstract}
The murine homologs of two viral oncogenes associated with tyrosine-specific kinase activity have been assigned to different loci in the mouse genome. The segregation of restriction site polymorphisms, as detected by probes that are specific for endogenous c-fes and c-src sequences, was followed in the DNA of recombinant inbred strains. The c-fes gene was mapped to the proximal portion of chromosome 7 , very close to the Gpi-1 locus, whereas c-src was linked to the Psp locus on the distal half of chromosome 2.
\end{abstract}

Oncogenic retroviruses contain transforming genes ( $\mathrm{v}$-onc genes) as an integral part of their genomes. It is believed that these viruses are a result of genetic recombination between retroviral sequences and distinct cellular sequences (c-onc genes), which are responsible for their acute transforming ability. The products encoded by some identified v-onc genes are associated with tyrosine-specific kinase activity (src, yes, $a b l, r o s$, and fes; reviewed in reference 2). Nucleotide sequence analysis $(9,26)$ and measurements of immunological cross-reactivity (1) support the idea that some of these oncogenes (the $s r c$ family) are evolutionarily related. The recent discovery of a gene that is homologous to $\mathrm{v}$-src and $\mathrm{v}-a b l$ in Drosophila melanogaster DNA further suggests that these oncogenes may have evolved from a common ancestral gene (14). It is of interest, therefore, to determine the relative locations of the cellular oncogenes in the mammalian genome and to find out whether members of the src family of genes are clustered on the same chromosome. Furthermore, the importance of the chromosomal locations of cellular transforming genes has been underscored by the demonstration that specific chromosomal translocations involving sites adjacent to specific c-onc genes are associated with murine and human lymphomas $(4,16,23,29)$. While this manuscript was still being prepared, c-src and c-fes were assigned to chromosomes 2 and 7, respectively, by the use of mouse-hamster somatic cell hybrids (A. Sakuguchi, personal communication) (18). We have mapped the mouse cellular homologs of $v$-fes and $v$-src to determine their relative chromosomal locations and to examine the possibility of their involvement in DNA rearrangements in the neoplastic transformation.

The regional chromosomal locations of c-fes and c-src were studied by following the segregation of restriction fragment length polymorphisms involving these genes within the DNA of two sets of recombinant inbred (RI) strains. These strains were derived from crosses between inbred strains $A / J$ (A) and C57BL/6J (B) or from crosses between strains $B$ and $D B A / 2 J(D)$, which resulted in $A \times B$ and $B \times A$ RI strains (22) and $B \times D$ RI strains (Jackson Laboratory, Bar Harbor, Me.; 30, 31), respectively.

Gene mapping of RI strains is accomplished in three steps. (i) Parental strains are screened for phenotypic or genotypic variation, in this case by using a nucleic acid probe (24) that

\footnotetext{
* Corresponding author.
}

detects a specific restriction site polymorphism in the DNA. (ii) The hybridization pattern of each of the RI strains is determined, and the resemblance to one parental strain or the other is ascertained, resulting in a strain distribution pattern (SDP) for a given genetic locus (see Table 1). (iii) The newly determined SDP is compared with SDPs of previously mapped genes to ascertain the degree of linkage and, thus, the chromosomal position of the particular gene $(8,30)$.

Polymorphism within the murine c-fes locus was detected by Southern blotting of restriction endonuclease-digested DNA of the two progenitor strains A and B, followed by hybridization with a c-fes probe (7). The pattern obtained by using DNA digested with four different restriction enzymes suggests the existence of a single locus containing the murine c-fes gene (Fig. 1). Except for EcoRI, no other restriction enzymes used (HindIII, PstI, and BglII in Fig. 1 and MspI, $P v u I I$, and $X b a I$, not shown) generated a polymorphic restriction pattern among $\mathrm{A}, \mathrm{B}$, and $\mathrm{D}$ mice. The EcoRI fragments that hybridize to c-fes differ in size: a 13-kilobase fragment is present in the A strain, and a 12-kilobase fragment is present in the B strain. The polymorphism in the size of the EcoRI fragments was used to follow the segregation of the variants in the $A \times B$ and $B \times A$ RI strains. A total of $30 \mathrm{RI}$ strains were tested; two representative Southern blots are shown in Fig. 2. That RI strains show both parental phenotypes is due to heterozygosis; i.e., the c-fes alleles were still segregating, and these RIs could not be used in the analysis. The results showed that 23 of the $30 \mathrm{RI}$ strains were homozygous with respect to the size of the EcoRI fragment containing the c-fes gene. Comparison of the SDP for c-fes with SDPs of other genes indicated tight linkage between cfes and genes located on chromosome 7 (Table 1). Thus, cfes is located between Gpi-l (glucose phosphate isomerase1) (15) and Tam-1 (tosyl arginine methylesterase-1) (27), with a distance of $2.6 \pm 2$ centimorgans from Gpi-1 and $6 \pm 4$ centimorgans from Tam-1.

A polymorphic pattern involving the murine c-src locus was obtained by using DNA of parental strains B and D, digested with HindIII and hybridized with a v-src probe (6). Other restriction enzymes, such as EcoRI, PstI, and BglII, generated identical patterns among the mouse strains tested. The v-src probe hybridizes to a single 13-kilobase DNA fragment in D mice and hybridizes with two DNA fragments of 16.5 and 14 kilobases in the DNA of $B$ mice. The segregation of these alleles was followed in $26 \mathrm{~B} \times \mathrm{D}$ RI mice, and the SDP was determined (Table 2). Analysis of SDPs indicated that the murine c-src gene is located on chromo- 
TABLE 1. SDP of c-fes and neighboring genes on chromosome 7

\begin{tabular}{|c|c|c|c|c|c|c|c|c|c|c|c|c|c|c|c|c|c|c|c|c|c|c|c|}
\hline \multirow{3}{*}{ Locus } & \multicolumn{23}{|c|}{ SDP of: } \\
\hline & \multicolumn{14}{|c|}{$\mathrm{A} \times \mathrm{B}$ RI strain } & \multicolumn{9}{|c|}{$\mathrm{B} \times \mathrm{A}$ RI strain } \\
\hline & 1 & 2 & 3 & 4 & 5 & 6 & 9 & 10 & 12 & 14 & 15 & 20 & 21 & 25 & 1 & 3 & 4 & 6 & 7 & 13 & 14 & 19 & 23 \\
\hline $\begin{array}{l}\text { c-fes } \\
\text { Gpi-1 } \\
\text { Tam-1 }^{a} \\
c^{d} \\
H_{b b^{e}}\end{array}$ & $\begin{array}{l}\text { B } \\
\text { B } \\
\text { B } \\
\text { B } \\
\text { B }\end{array}$ & $\begin{array}{l}\text { A } \\
\text { A } \\
\text { B } \\
\text { A } \\
\text { A }\end{array}$ & $\begin{array}{l}\text { A } \\
\text { A } \\
\text { A } \\
\text { A } \\
\text { A }\end{array}$ & $\begin{array}{l}\text { B } \\
\text { B } \\
\text { B } \\
\text { B } \\
\text { B }\end{array}$ & $\begin{array}{l}\text { A } \\
\text { A } \\
\text { A } \\
\text { B } \\
\text { A }\end{array}$ & $\begin{array}{l}\text { A } \\
\text { A } \\
\text { A } \\
\text { A } \\
\text { A }\end{array}$ & $\begin{array}{l}\text { A } \\
\text { A } \\
\text { A } \\
\text { A } \\
\text { A }\end{array}$ & $\begin{array}{l}\text { B } \\
\text { B } \\
\text { B } \\
\text { B } \\
\text { B }\end{array}$ & $\begin{array}{l}\text { A } \\
\text { A } \\
\text { A } \\
\text { A } \\
\text { A }\end{array}$ & $\begin{array}{l}\text { A } \\
\text { A } \\
\text { B } \\
\text { A } \\
\text { A }\end{array}$ & $\begin{array}{l}\text { A } \\
\text { A } \\
\text { A } \\
\text { B } \\
\text { B }\end{array}$ & $\begin{array}{l}\text { B } \\
\text { B } \\
\text { B } \\
\text { B } \\
\text { B }\end{array}$ & $\begin{array}{l}\text { A } \\
\text { A } \\
\text { A } \\
\text { B } \\
\text { B }\end{array}$ & $\begin{array}{c}\mathrm{B} \\
\overline{\mathrm{B}}_{b}^{\mathrm{B}} \\
\mathrm{B}\end{array}$ & $\begin{array}{l}\text { B } \\
\text { B } \\
\text { B } \\
\text { B } \\
\text { B }\end{array}$ & $\begin{array}{l}\mathbf{B} \\
\mathbf{B} \\
\mathbf{B} \\
\mathbf{B} \\
\mathbf{B}\end{array}$ & $\begin{array}{l}\text { A } \\
\text { B } \\
\text { A } \\
\text { A } \\
\text { A }\end{array}$ & $\begin{array}{l}\text { A } \\
\text { A } \\
\text { A } \\
\text { B } \\
\text { B }\end{array}$ & $\begin{array}{l}\text { A } \\
\text { A } \\
\text { B } \\
\text { A } \\
\text { A }\end{array}$ & $\begin{array}{l}\text { A } \\
\text { A } \\
\text { A } \\
\text { A } \\
\text { A }\end{array}$ & $\begin{array}{c}A_{b} \\
\bar{A}^{A} \\
A \\
A\end{array}$ & $\begin{array}{l}\text { A } \\
\text { B } \\
\text { B } \\
\text { A } \\
\text { A }\end{array}$ & $\begin{array}{l}\text { A } \\
\text { A } \\
\text { A } \\
\text { B } \\
\text { A }\end{array}$ \\
\hline
\end{tabular}

${ }^{a}$ Glucose phosphate isomerase-1 (15).

b - Not tested.

c Tosyl arginine methylesterase-1 (27).

${ }^{d}$ Coat color (albino).

e Hemoglobin chain (32).

some 2 by linkage ( $2.2 \pm 1.6$ centimorgans) to $P s p$ (parotid secretory protein) (13), which resides on the distal half of the chromosome. However, the orientation of $P s p$ and c-src with respect to the centromere was not posssible because of a lack of SDPs for other genetic markers on this portion of chromosome 2 . This result places c-src more than 20 centimorgans away from the $c-a b l$ gene, another member of the tyrosine kinase genes that maps very near to the $\beta_{2}$-microglobulin gene (21). It has been suggested that the genesis of myeloid leukemia is greatly influenced by genetic information of chromosome 2 since partial deletions of chromosome 2 have been associated with 49 of 52 cases of the disease
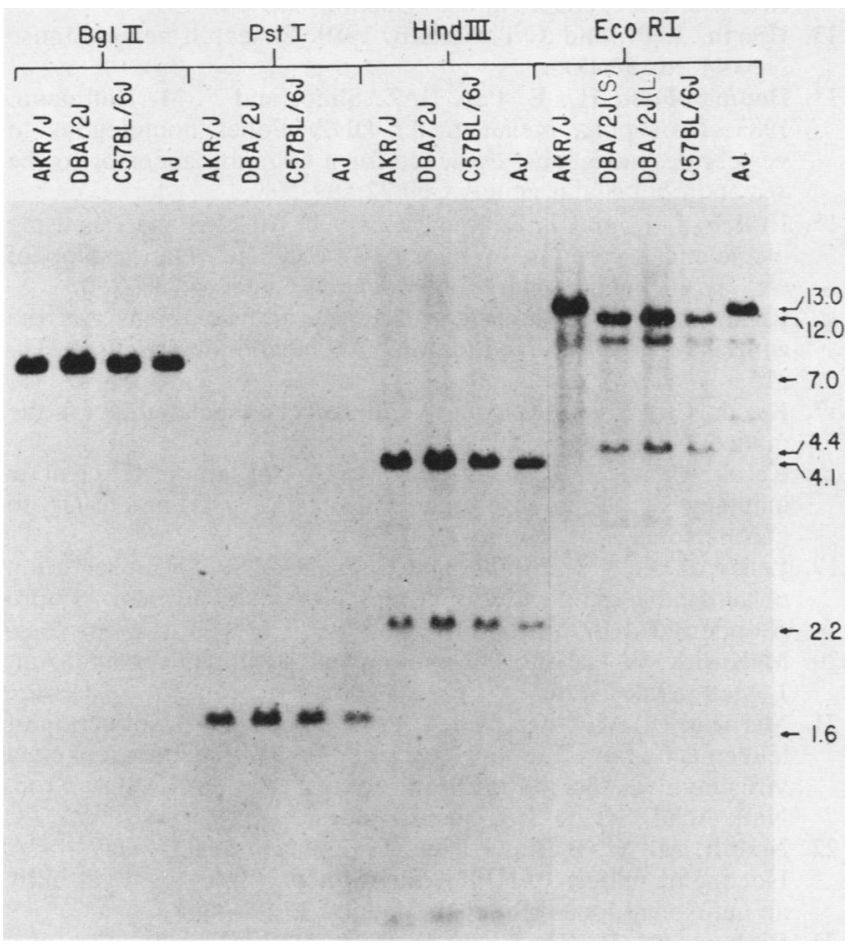

FIG. 1. Detection of c-fes sequences in the DNA of four inbred mouse strains. High-molecular-weight liver DNA was digested with endonuclease restriction enzymes $(4 \mathrm{U} / \mu \mathrm{g})$, followed by electrophoresis and Southern transfer (28). The blot was hybridized with a ${ }^{32} \mathrm{P}$ labeled c-fes probe, recombinant plasmid pN26 (7). Spleen (S) and liver (L) DNAs of D mice digested with EcoRI exhibit an identical hybridization pattern. The variation between DNA of $A$ and $B$ mice was used to determine the segregation of the c-fes gene in the $\mathrm{A} \times \mathrm{B}$ RI strains. Numbers on the right indicate fragment size in kilobases.
(11). Further studies are necessary to examine the involvement of c-src and c-abl on chromosome 2 with leukemia.

The mouse c-fes gene maps to the proximal portion of chromosome 7 between the Gpi-1 and Tam-1 genes. It is interesting that although chromosome 7 has not been shown thus far to be involved in specific translocations in malignancies, a number of genes potentially involved in oncogenesis have been mapped to chromosome 7 . These include the ecotropic murine leukemia virus loci $A k v-l$ of AKR mice and $F g v-1$ of $\mathrm{C} 3 \mathrm{H} / \mathrm{Fg}$ mice (17), two endogenous mink cell focusinducing viral sequences ( $2 \mathrm{a}), M t v-I$ (a mammary tumor viral sequence [31]), and the c-Ha-ras-1 gene (18).

Studies with human-mouse somatic cell hybrids assigned the human c-fes gene to chromosome $15(5,12)$, and more recently it has been sublocalized to $15 \mathrm{q} 25-26$ by in situ hybridization (10). Comparative mapping suggests that a portion of mouse chromosome 7 is homologous to a region of human chromosome 15 , since the mitochondrial isocitrate

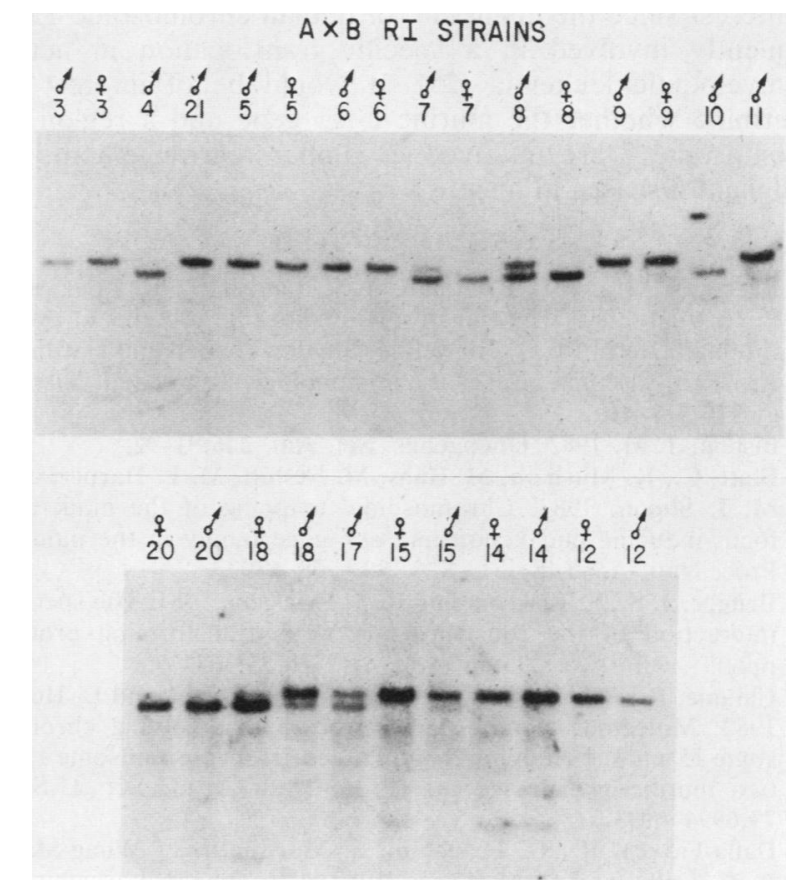

FIG. 2. Segregation of the allelic EcoRI restriction fragments in $A \times B$ RI strains as shown by hybridization with the c-fes probe. Strains heterozygous at the $c-f e s$ locus $(\mathrm{A} \times \mathrm{B} 7, \mathrm{~A} \times \mathrm{B} 8, \mathrm{~A} \times \mathrm{B} 17$, and $A \times B$ 18) were not included in the SDP. 
TABLE 2. SDP of c-src and Psp

\begin{tabular}{|c|c|c|c|c|c|c|c|c|c|c|c|c|c|c|c|c|c|c|c|c|c|c|c|c|c|c|}
\hline \multirow{2}{*}{ Locus } & \multicolumn{26}{|c|}{ SDP of $B \times D$ RI strains } \\
\hline & 1 & 2 & 5 & 6 & 8 & 9 & 11 & 12 & 13 & 14 & 15 & 16 & 18 & 19 & 20 & 21 & 22 & 23 & 24 & 25 & 27 & 28 & 29 & 30 & 31 & 32 \\
\hline C-src & D & D & B & D & D & $\mathrm{D}$ & $\mathrm{D}$ & D & D & B & B & D & D & B & D & D & B & $\mathrm{D}$ & D & D & D & B & D & D & D & D \\
\hline$P s p^{a}$ & $\mathrm{D}$ & $\mathrm{D}$ & B & $\mathrm{D}$ & $\mathrm{D}$ & $\mathrm{D}$ & $\mathrm{D}$ & $\mathrm{D}$ & B & B & B & $\mathrm{D}$ & $\mathrm{D}$ & $\mathrm{D}$ & $\mathrm{D}$ & $\mathrm{D}$ & B & $\mathrm{D}$ & $\mathrm{D}$ & D & D & B & D & D & $\mathrm{D}$ & D \\
\hline
\end{tabular}

${ }^{a}$ Parotid secretory protein (13).

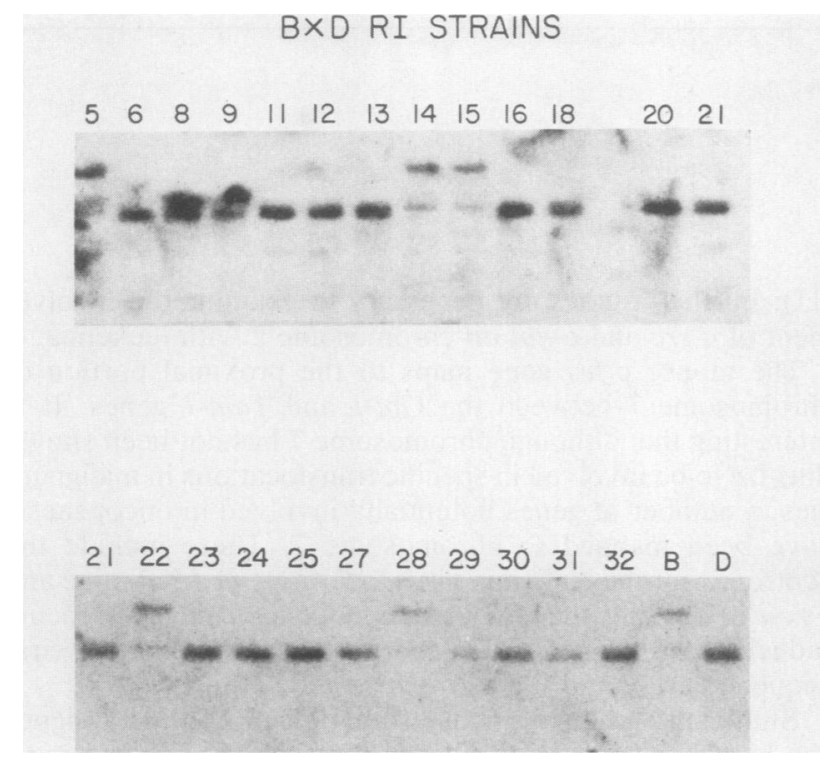

FIG. 3. Segregation of the allelic HindIII restriction fragments in $B \times D$ RI strains as shown by hybridization with the v-src probe (6).

dehydrogenase locus (Idh-2) is located on mouse chromosome 7 (19) and on 15q21-qter in humans (20). This finding is of interest since the distal half of human chromosome 15 is frequently involved in a specific translocation in acute promyelocytic leukemia (25). It would be of interest to determine whether the murine c-fes gene and a region of chromosome 7 are involved in similar rearrangements in malignant diseases in mice.

\section{LITERATURE CITED}

1. Barbacid, M., M. L. Breitman, A. V. Lauver, L. K. Long, and P. K. Vogt. 1981. The transformation specific proteins of avian (Fujinami and PRC11) and feline (Snyder-Theilen and GardnerArnstein) sarcoma viruses are immunologically related. Virology 110:411-419.

2. Bishop, J. M. 1982. Oncogenes. Sci. Am. 246:81-92.

2a.Blatt, C., K. Mileham, M. Haas, M. Nesbitt, M. E. Harper, and M. I. Simon. 1983. Chromosomal mapping of the mink cell focus-inducing and xenotropic env gene family in the mouse. Proc. Natl. Acad. Sci. U.S.A. 80:6298-6302.

3. Brugge, J. S., E. Erikson, and R. L. Erickson. 1981. The specific interaction of the rous sarcoma virus transforming protein pp60 ${ }^{s c c}$. with two cellular proteins. Cell 25:363-372.

4. Calame, K., S. Kim, P. Lalley, R. Hill, M. Davis, and L. Hood. 1982. Molecular cloning of translocations involving chromosome 15 and the immunoglobulin $\mathrm{C}$ gene from chromosome 12 in two murine plasmacytomas. Proc. Natl. Acad. Sci. U.S.A. 79:6994-6998.

5. Dalla-Favera, R., G. Franchini, S. Martinotti, F. Wong-Staal, R. C. Gallo, and C. M. Croce. 1982. Chromosomal assignment of the human homologues of feline sarcoma virus and avian myeloblastosis virus onc genes. Proc. Natl. Acad. Sci. U.S.A. 79:4714-4717.

6. Delorbe, W. J., P. A. Luciw, H. M. Goodman, H. E. Varmus, and J. M. Bishop. 1980. Molecular cloning and characterization of avian sarcoma virus circular DNA molecules. J. Virol. 36:5061.

7. Franchini, G., E. P. Gelmann, R. Dalla Favera, R. C. Gallo, and F. Wong-Staal. 1982. Human gene (c-fes) related to the onc sequences of Snyder-Theilen feline sarcoma virus. Mol. Cell. Biol. 2:1014-1019.

8. Haldane, J. B. S., and C. H. Waddington. 1931. Inbreeding and linkage. Genetics 16:357-374.

9. Hampe, A., I. Laprevotte, F. Galibert, L. A. Fedele, and C. J. Sherr. 1982. Nucleotide sequences of feline retroviral oncogenes $(\mathrm{v}-\mathrm{fes})$ provide evidence for a family of tyrosine-specific protein kinase genes. Cell 30:775-785.

10. Harper, M. E., G. Franchini, J. Love, M. I. Simon, R. C. Gallo, and F. Wong-Staal. 1983. Chromosomal sublocalization of human c-myb and c-fes cellular onc genes. Nature (London) 304:169-171.

11. Hayata, I., M. Seki, K. Yoshida, K. Hirashima, T. Sado, J. Yamagiwa, and T. Ishihara. 1983. Chromosomal aberrations observed in 52 mouse myeloid leukemias. Cancer Res. 43:367373.

12. Heisterkamp, N., J. Groffen, J. R. Stephenson, N. K. Spurr, P. N. Goodfellow, E. Solomon, B. Carritt, and W. F. Bodmer. 1982. Chromosomal localization of human cellular homologs of two viral oncogenes. Nature (London) 299:747-749.

13. Hjorth, J. P., and J. T. Nielsen. 1980. Research news. Mouse News Lett: 62:41.

14. Hoffman-Falk, H., E. Paz, B. Z. Shilo, and F. M. Hoffmann. 1983. Drosophila melanogaster DNA clones homologous to vertebrate oncogenes: evidence for a common ancestor to the $s r c$ and $a b l$ cellular genes. Cell 32:589-598.

15. Hutton, J. J., and T. H. Roderick. 1970. Linkage analysis using biochemical variants in mice. III. Linkage relationships of eleven biochemical markers. Biochem. Genet. 4:339-350.

16. Klien, G. 1983. Specific chromosomal translocations and the genesis of B-cell-derived tumors in mice and men. Cell 32:311315 .

17. Kozak, C. A. 1982 . Retroviral and cancer-associated loci in the mouse. Genet. Maps 2:294-297.

18. Kozak, C. A., J. F. Sears, and M. D. Hoggan. 1983. Genetic mapping of the mouse oncogenes c-Ha-ras-1 and c-fes to chromosome 7. J. Virol. 47:217-220.

19. Lalley, P. A., J. D. Minna, and U. Francke. 1978. Conservation of autosomal gene synteny groups in mouse and man. Nature (London) 274:160-162.

20. McKusick, V. A. 1980. The anatomy of the human genome. Am. J. Med. 69:267-276.

21. Meruelo, D., M. Offer, and A. Rossomundo. 1983. Induction of leukemia by both fractional $\mathrm{x}$-irradiation and radiation leukemia virus involves loci in the chromosome 2 segment H-30-A. Proc. Natl. Acad. Sci. U.S.A. 80:462-466.

22. Nesbitt, M. N., B. Bakay, M. B. Gardner, and C. Day. 1979. Isoenzyme pattern of HPRT in murine erythrocytes: control by an autosomal locus. Biochem. Genet. 17:954-964.

23. Rechavi, G., D. Givol, and E. Canaani. 1982. Activation of a cellular oncogene by DNA rearrangement: possible involvement of an IS-like element. Nature (London) 300:607-611.

24. Rigby, P. W. J., M. Dieckmann, C. Rhodes, and P. Berg. 1977. Labeling deoxyribonucleic acid to high specific activity in vitro by nick translation with DNA polymerase. I. J. Mol. Biol. 113:237-251.

25. Rowley, J. D. 1983. Human oncogene locations and chromosome aberrations. Nature (London) 301:290-291.

26. Shibuya, M., and H. Hanafusa. 1982. Nucleotide sequence of 
Fujinami sarcoma virus: evolutionary relationship of its transforming gene with transforming genes of other sarcoma viruses. Cell 30:787-795.

27. Skow, L. C. 1978. Genetic variation at a locus (Tam-1) for submaxillary gland protease in the mouse and its location on chromosome 7. Genetics 90:713-724.

28. Southern, E. M. 1975. Detection of specific sequences among DNA fragments separated by gel electrophoresis. J. Mol. Biol. 98:503-517.

29. Taub, R., I. Kirsch, C. Morton, G. Lenoir, D. Swan, S. Tronick, S. Aaronson, and P. Leder. 1982. Translocation of the c-myc gene into the immunoglobulin heavy chain locus in human
Burkitt lymphoma and murine plasmacytoma cells. Proc. Natl. Acad. Sci. U.S.A. 79:7837-7841.

30. Taylor, B. A. 1978. Recombinant inbred strains: use in gene mapping, p. 423-438. In H. C. Morse III (ed.), Origins of inbred mice. Academic Press, Inc., New York.

31. Traina, V. L., B. A. Tailor, and J. C. Cohen. 1981. Genetic mapping of endogenous mouse mammary tumor viruses: locus characterization, segregation, and chromosomal distribution. J. Virol. 40:735-744.

32. Wood, A. W., and B. A. Taylor. 1979. Genetic regulation of coumarin hydroxylase activity in mice. Evidence for a single locus control on chromosome 7. J. Biol. Chem. 254:5647-5651. 